\title{
Profile of Students' Critical Thinking Skills and the Implementation of PBLRQA based on Blended Learning in Senior High School
}

\author{
${ }^{1}$ Febtya Lailatul Badriyah, ${ }^{2}$ Husni Mubarok, ${ }^{1 *}$ Binar Kurnia Prahani \\ ${ }^{1}$ State University of Surabaya, Indonesia \\ ${ }^{2}$ National Taiwan University of Science and Technology, Taiwan \\ *Corresponding Author e-mail: binarprahani@unesa.ac.id \\ Received: June 2021; Revised: June 2021; Published: June 2021
}

\begin{abstract}
This research aimeds to obtain the profile of students' critical thinking skills and the implementation of PBLRQA based on blended learning in high school. This research is a descriptive preliminary study with a saturated sampling technique was taken by 123 students. The method of gathering information with a used a written test, response questionnaire students, and teacher interviews. The analysis was conducted using qualitative descriptive analysis techniques. The result showed that critical thinking skills in the very low category. With the acquisitions of the very low category as many as namely 110 students, the low category as many as 12 students being low, the medium category as many as and 1 student, but in the high and very high categories there are no students who achieve it. The research of the study concluded that the students generally in low critical thinking skills, so it is necessary to change the learning model to improve critical thinking skills, namely by the implementation of PBLRQA based on blended learning.
\end{abstract}

Keywords: Blended Learning; Critical Thinking; PBLRQA

How to Cite: Badriyah, F., Mubarok, H., \& Prahani, B. (2021). Profile of Students' Critical Thinking Skills and the Implementation of PBLRQA based on Blended Learning in Senior High School. Prisma Sains: Jurnal Pengkajian Ilmu dan Pembelajaran Matematika dan IPA IKIP Mataram, 9(1), 38-51. doi:https://doi.org/10.33394/j-ps.v9i1.3911

https://doi.org/10.33394/j-ps.v9i1.3911

\section{INTRODUCTION}

The progress of education in the 21 st century has an important role in determining the quality of education. Student success depends on the achievement of 21 st century skills that oblige students to have competencies in knowledge, attitudes, and skills (Asrizal, 2019). The development of the 21 st century is indicated by advances in science and technology to overcome the challenges that arise (Listiana et al., 2020). Responding to this challenge requires change. These changes emphasize authentic learning and assessment processes that result in students' quality life skills and character (Yulianti, 2016). Partnership for 21st Century Skills finds 21st century skills focused on critical thinking, creativity, communication, and problem solving skills towards information technology (Susilawati, 2015). So that every student is required to have these skills in facing challenges and problems that arise in the 21 st century.

In the process of learning physics emphasizes aspects of understanding rather than memorization. So that in understanding the concept of physics is one of the keys to success which lies in the way students think. Therefore, it is important that students are trained in critical thinking skills. This skill describes the stages of students in higher order thinking, which aims to improve the quality of thinking by starting with understanding the problem in detail, identifying problems by stating the right reasons, making conclusions according to data and based on convincing arguments, and applying self-ability in decision making by conducting analysis and evaluation (Facione, 2013; Prameswari, 2018). The indicators used 
in this study include analysis, evaluation, interpretation, and inferences (Facione, 2013). Based on the results of the preliminary study, the aim of this study was to obtain a profile of the critical thinking skills of students at the high school level.

Critical thinking skills can be used with observation, organizing, conveying, investigating to produce the right data and facts (Yuliati, 2018). The development of authentic critical thinking skills can be trained with a student focused learning model. The application of the learning model is the most important factor in strengthening student skills (Sungur \& Tekkaya, 2016). One of them is the learning model strategy proposed by the Indonesian Ministry of Education and Culture in increasing students critical thinking skills, namely problem based learning (PBL) (Mundilarto \& Ismoyo, 2017). Education and Culture in increasing students critical thinking skills, namely problem based learning (PBL) (Mundilarto \& Ismoyo, 2017).

The PBL model has characteristics that show that learning is student focused, the problems presented refer to authentic problems by linking small groups, information is obtained independently, and the teacher as a facilitator (Bakri et al., 2021). The PBL model has five syntaxs, namely presenting problems for students, organizing students, conducting individual and group investigations, presenting the results of investigations, and analyzing and testing processes in solving problems (Arrends, 2008).

The use of this PBL model shows various advantages, one of which can improve critical thinking skills. But the PBL model also has drawbacks, one of which is that students do not have an interest because the problems are too difficult, and the use of the PBL model takes more time than conventional learning strategies (Bustami \& Corebima, 2019). So that a learning strategy is needed that is expected to be able to overcome the shortcomings of PBL, namely the reading, questioning, and answering (RQA) strategy based on blended learning. The RQA learning strategy is that students read and understand the content of the reading (reading process), then students refer to the content of the reading (question process) and answer the questions they have made (answer process) (Bahtiar, 2013). PBL and RQA syntax in PBLRQA aims to train students in student focused learning so that students are responsible for managing the learning process (Bahri, et al., 2021). Through RQA activities, students will find conditions in which students will learn and think critically which can improve students critical thinking skills (Bustami \& Corebima, 2019).

Regarding the problem of time, the PBL model can use a blended learning based learning system. The idea of NACOL (North American Council For Online Learning) is in the learning process applying technology (Hasmunarti, et al., 2018). Blended learning is learning with a combination system offline and online (Graham, 2005; Sharma, 2010; Bahri, et al., 2021). In blended learning based learning, the process of delivering information is not only centered on the teacher, but can independently seek information by opening websites through search engines, portals, blogs, learning software (Faisal, 2011; Rosenthal \& Weith, 2012; Hasmunarti, et al., 2018). Online learning can become a learning model innovation students interaction through critical thinking skills that can support the learning process (Alexander, 2000; Forsyth, 2001; Deore, 2012).

Based on a preliminary study through written tests, questionnaires, and teacher interviews that have been conducted at Kabuh state high school. The results showed that the low critical thinking skills of students and the learning process that had been carried out was categorized as not yet effective. So we need a varied learning model that is more effective, quality, and makes it easier for students to improve students critical thinking skills at the upper secondary level and be able to answer challenges and problems in the 21 st century. Based on the description above, the main objective of this research is to obtain a profile of students critical thinking skills at the high school level and the implementation of problem based learning and reading, questioning, \& answering (PBLRQA) based on blended learning. The introduction should contain (in order) the general background, state of the art as the basis for the scientific update statements, and the research problem or hypotheses. At the end of the 
introduction, the purpose of the article review should be written. In the format of scientific articles, literature reviews are not allowed as in the research report but are created in the form of a recent study to display the scientific novelty of the article.

\section{METHOD}

This research uses a preliminary study with a descriptive research design and to test the hypothesis. This research aims to identify the level of students' critical thinking skills as a form of recommendation in developing various learning models to be applied to improve students' critical thinking skills in physics learning materials, namely business and energy materials. To obtain complete clarity, each research variable needs to be operationalized in order to obtain the type of data and information needed to answer the research question.

This research was conducted online via google form on February 26, 2021, at Kabuh state high school. The population of this study was four grade X IPA consisting of 123 students with a saturated sampling technique. Data from 123 respondents were collected using research instruments. The instrument is through a written test, student response questionnaires, and teacher interviews after revising the instrument validation. The data analysis technique is the process of searching for data (Sugiyono, 2010) which is used in this study is a qualitative descriptive analysis technique. A written test is a test containing questions and must be answered by students by giving written answers. Each question must be based on predetermined indicators. The written test used is a critical thinking essay test (Ennis, 2011) to assess students thinking skills. The instrument used is a description of the questions with each question having indicators of critical thinking skills, namely analysis, evaluation, interpretation, and inference. This critical thinking skill test consists of material about work and energy, which consists of twelve essay questions with each indicator consisting of three questions.

The questionnaire is a research instrument consisting of a number of questions aimed at obtaining information from respondents. The questionnaire used in this study aims to obtain an overview of the learning process that has been carried out by students and the role of the teacher. As well as students perspectives based on critical thinking skills and problem based learning learning models with reading, questioning, and answering (PBLRQA) based on blended learning, which presented ten questions in a questionnaire filled out by students.

Interviews with teachers containing a number of six questions that can provide information about the process of teaching and learning activities carried out by the teacher. This interview aims to adjust the results of student answers with the teacher. The information sought is whether a learning model has been implemented that can improve students' critical thinking skills and teacher opinions if the problem based learning model is implemented using blended learning based reading, questioning, and answering (PBLRQA).

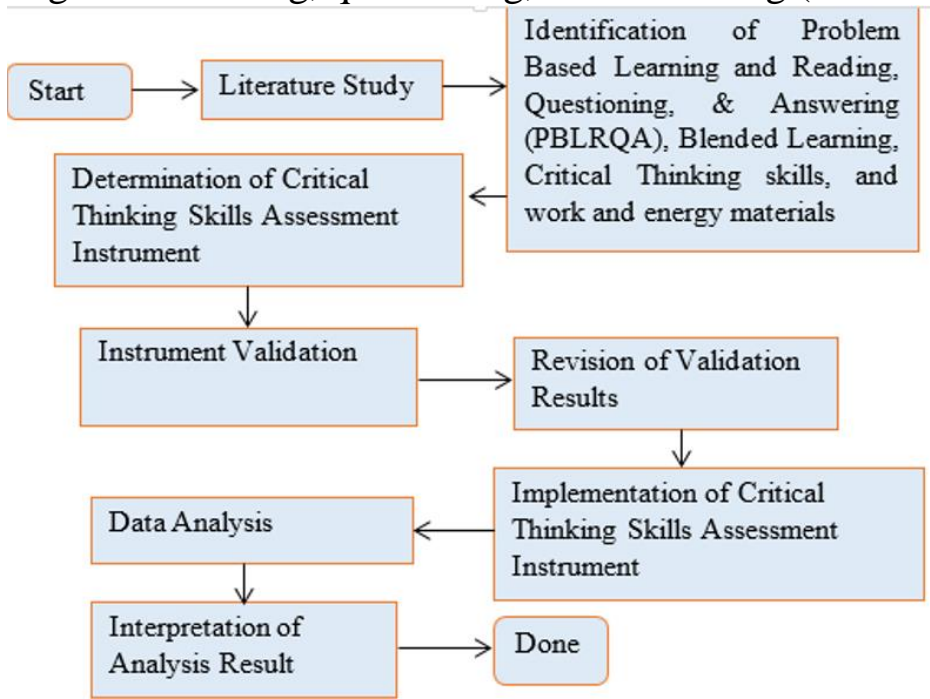

Figure 1. Flowchart of research 
The data collected was then analyzed. For the results of students answers in completing written tests in order to get a profile of students critical thinking skills, they are categorized according to the highest scoring criteria for each criterion. The research flow should be presented in a complete section with information. Captions of the image position as part of the image title (figure caption) are not part of the Figure. The methods used in completing the study are written in this section.

Table 1. Criteria for the ideal assessment of students critical thinking skills based on Setyowati (2011).

\begin{tabular}{ll}
\hline Range of Score & Category \\
\hline $81.25<X<100$ & Very High \\
$71.50<X<81.25$ & High \\
$62.50<X<71.50$ & Medium \\
$43.75<X<62.50$ & Low \\
$0<X<43.75$ & Very Low \\
\hline
\end{tabular}

This research was conducted by following the research flowchart as shown in Figure 1. Increasing the profile of students critical thinking skills is assessed from the success of education in carrying out learning process activities by implementing appropriate learning models. The resulting research data were then analyzed using qualitative descriptive analysis techniques. This technique aims to analyze data by describing data information collected based on actual conditions (Sugiyono, 2010).

\section{RESULTS AND DISCUSSION}

The research results that have been carried out are aimed at getting a profile of students' critical thinking skills, especially material work and energy.

\section{Critical Thinking Skills Test}

The research was conducted with a written test instrument consisting of an essay test with a total of twelve questions with each indicator consisting of three questions equipped with four indicators of critical thinking skills consisting of indicators of analysis, evaluation, interpretation, and inference (Facione, 2013). Next, students are asked to provide answers according to the problems given. The value of students critical thinking skill level is calculated based on students answers. Based on the question instruments given, students are required to be able to analyze the relationship of concepts in solving problems, can draw conclusions using scientific reasoning, can evaluate by writing problem solving, and interpretation that can describe the problems given.

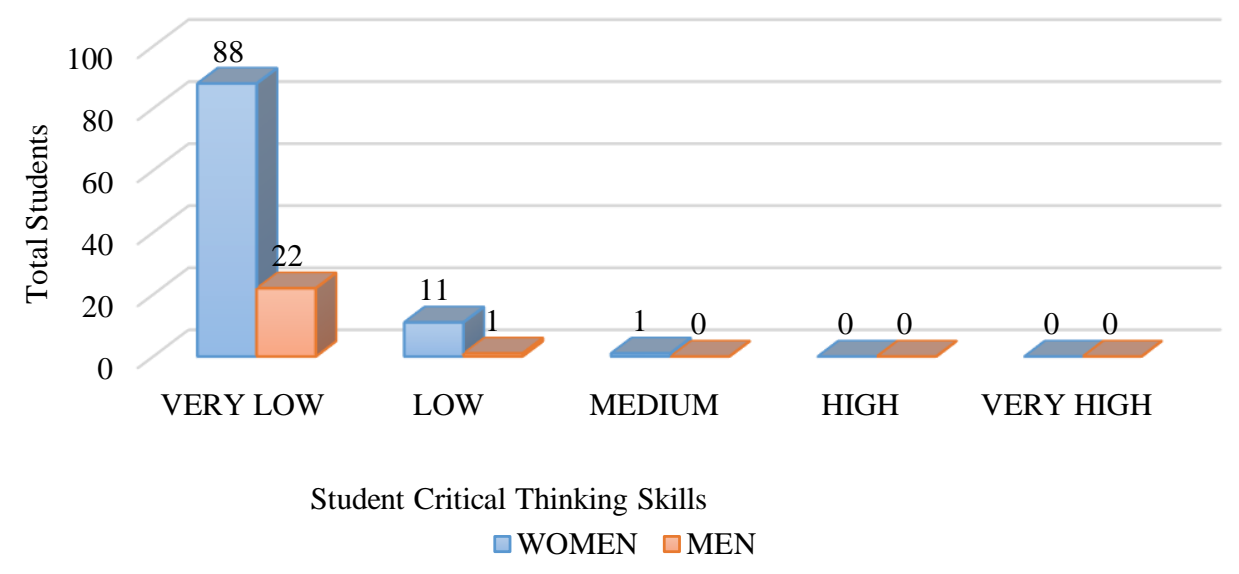

Figure 2. The result critical thinking skills level of all students, both women, and men. 
The scoring used is a score adapted from (Facione \& Ennis, 2011). With a scoring range, each question gets 5 points. For answers with a score of 5 with all correct, clear, and specific concepts and facts; score four if only part of the concept is correct and clear; score three if some of the concepts are correct and clear, but the reasons are not correct; score 2 if the concept is redundant but not based on data and not supported by facts; score 1 if all concepts and descriptions are not correct; score 0 if you don't answer the question. The assessment has been carried out based on the criteria in table 1 so that the results are presented in Figure 2.

Figure two shows the results of the profile of students critical thinking skills, both men and women, are very diverse, namely, there is a significant difference. This difference shows that the level of critical thinking skills of female students is higher than that of male students. Based on the graph, the categories of critical thinking skills are very low, low, and medium. But there are no students who get high and very high categories. This shows the less critical thinking skills of high school students. In the very low category, a many as 88 women and 22 men, low category as many as 11 women and one man, medium category as many as one woman, no one meets the high category, and no one meets the very high category. The results of students overall critical thinking skills according to the Facione indicator. These results are presented in Figure 3.

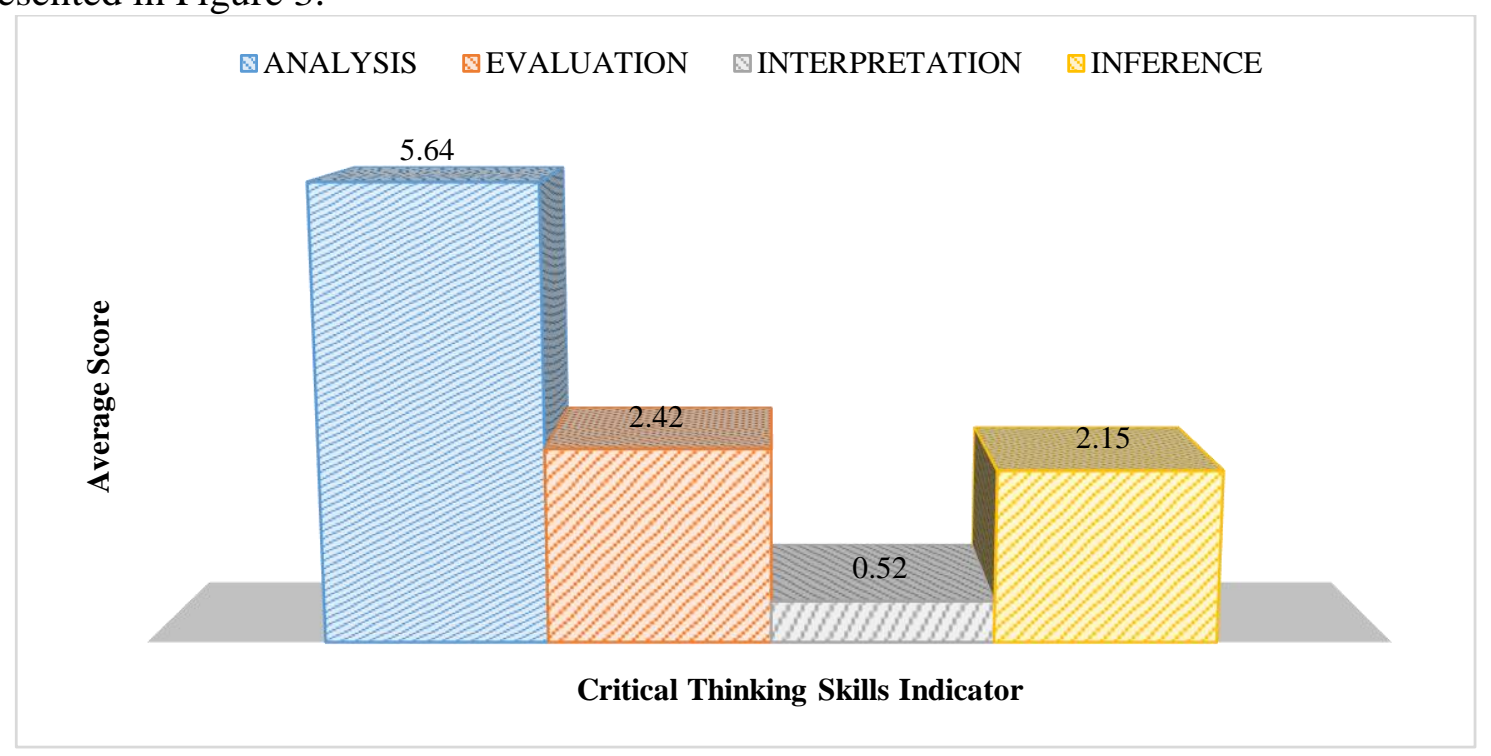

Figure 3. The results of the average value based on indicators of critical thinking skills.

At the indicator stage of analysis, students in identifying inferential relationships must be based on concepts, opinions and arguments clearly. At the evaluation stage, students in answering questions on questions require the delivery of thoughts based on systematic decisions and reasons. At the interpretation stage, students are able to understand the procedures or stages in writing answers correctly. At the inference stage, students in drawing conclusions must be based on clear and appropriate reasons. Figure 3 shows the results of each critical thinking indicator, namely analysis, evaluation, interpretation, and inference. In the analysis indicators obtained an average of 5.64; evaluation indicators obtained an average of 2.42; interpretation indicators obtained an average of 0.52 ; and the inference indicator obtained an average of 2.15. The graph shows the results of the answers based on the lowest indicator, namely interpretation, while the highest is in the analysis indicator. Differences in students critical thinking skills for men and women can be calculated based on each indicator of critical thinking skills according to Facione. The results are presented in Figure 4. 


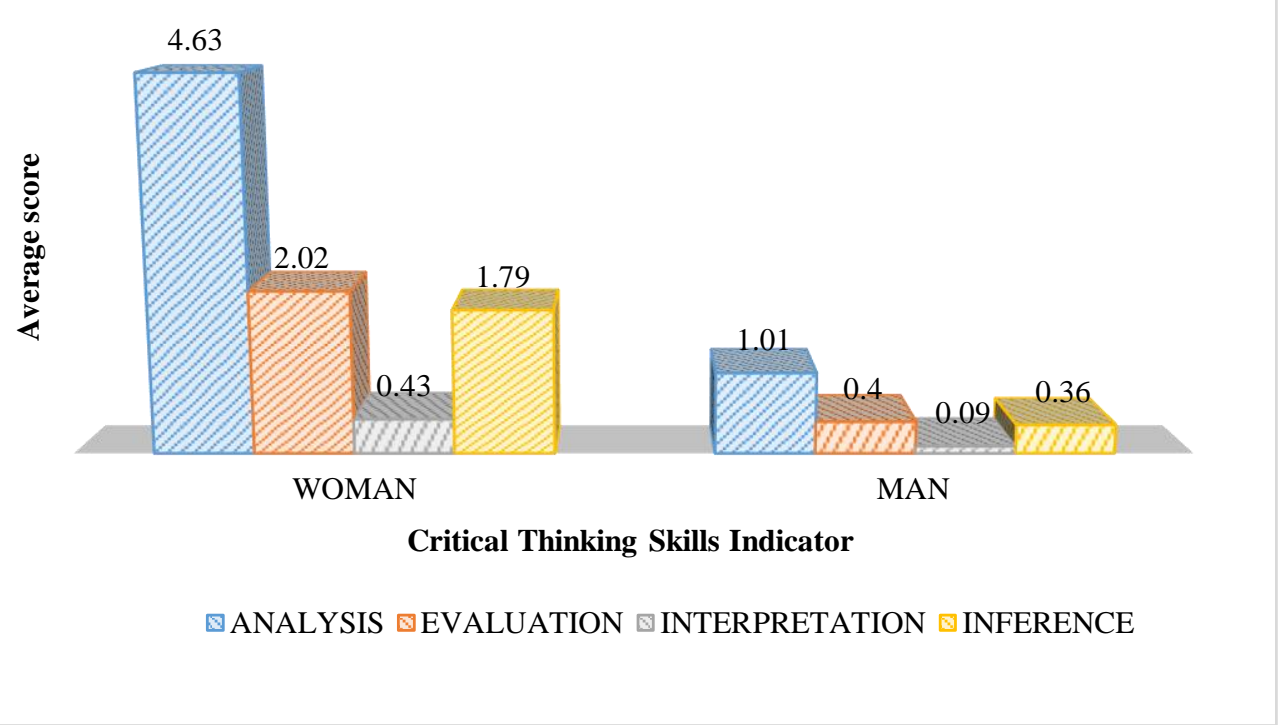

Figure 4. The results of differences in critical thinking skills of men and women based on each indicator of critical thinking skills.

The results obtained based on the critical thinking skills of men and women students showed a substantial difference that the score of women students was higher than that of men students. This agrees with the research found (Mahana \& Erna, 2011), which says that gender differences show that women's critical thinking profiles are higher than men's. This is because women are able to process and respond to information quickly, make systematic decisions, and have better long-term memory so that in terms of higher order thinking skills, they are higher than men. (Witelson, et al., 1995; Ricketts 2004). The results of the written test of critical thinking skills by one of the students can be shown in the following.

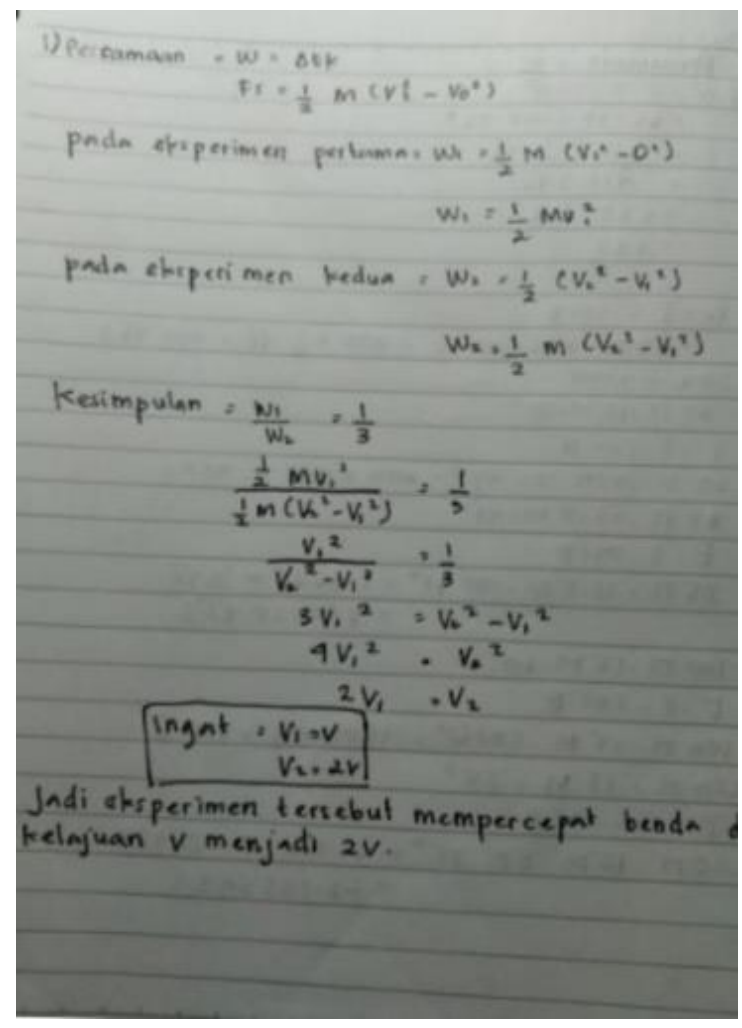

Figure 5. Completion of analysis indicators. 
In the Figure 5, students are asked to identify the ratio of work by analyzing the speed of a moving object. Based on the students answers, it indicates that students conduct problem analysis by generalizing ideas based on facts and identifying them well with the right steps.

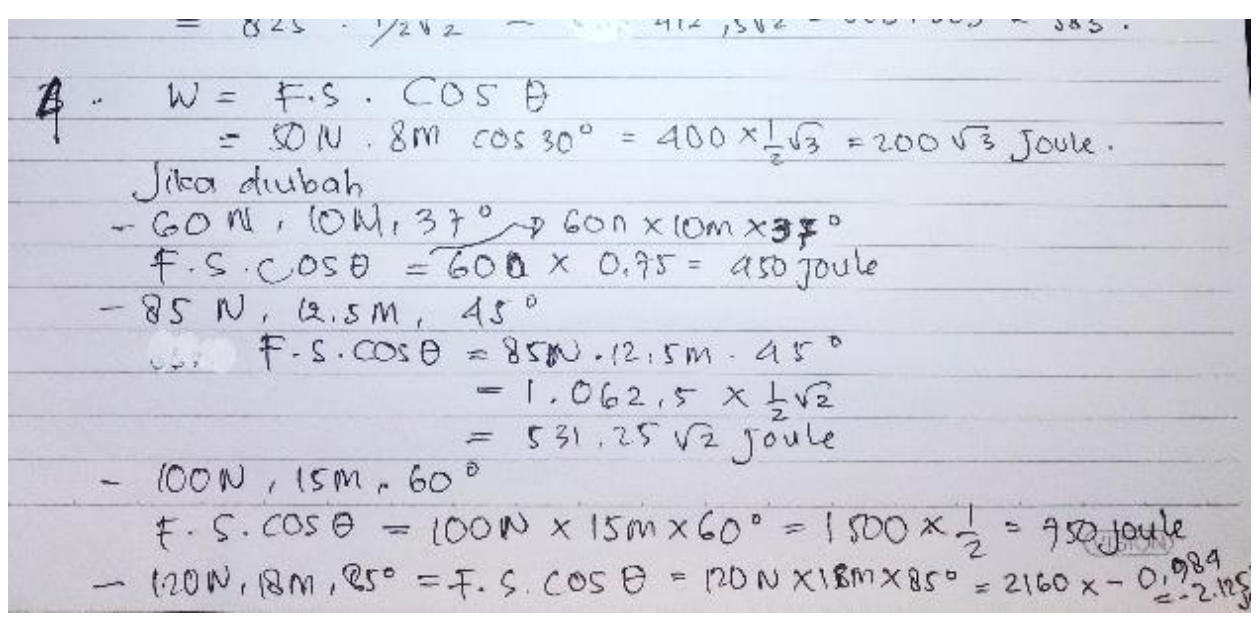

Figure 6. Completion of evaluation indicators.

In Figure 6, students are asked to evaluate the problem objectively and choose relevant information to solve the problem regarding the greatest business value. However, students in delivering their opinions or solutions are still not quite right in their perceptions.

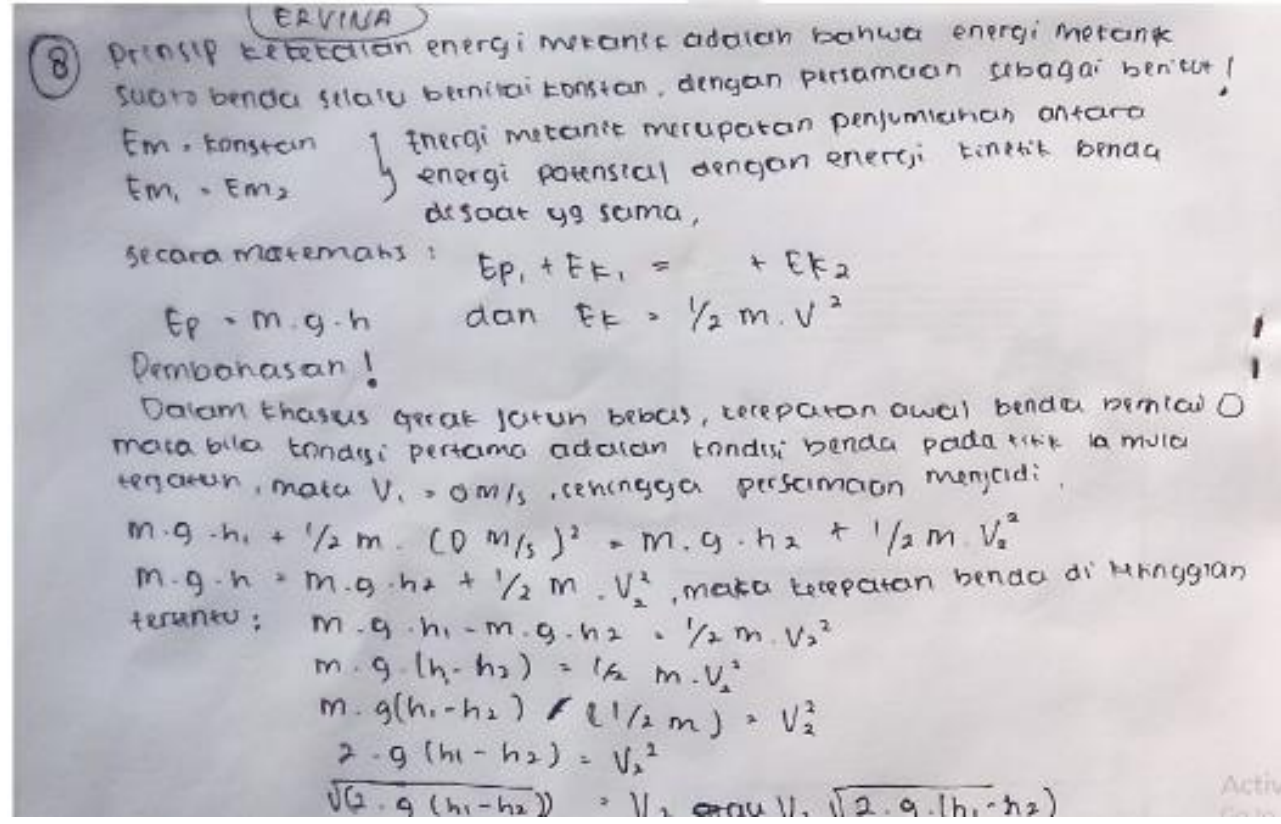

Figure 7. Completion of interpretation indicators.

In Figure 7, it shows students are asked to express by writing down the facts of the argument by connecting what is known from the problem about the problem of the law of conservation of mechanical energy completely and clearly. However, students are still not quite right in answering it. 


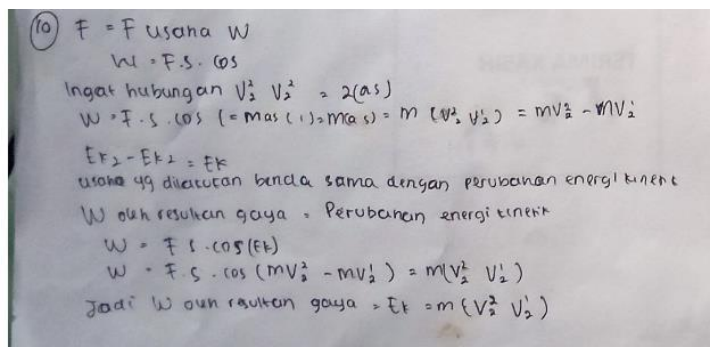

Figure 8. Completion of inference indicators.

In Figure 8, it shows that students are asked to make conclusions by solving the problem of the resultant force contained in an object with a relevant tendency to be detailed, complete, and clear. However, the students answers do not match the problems that arise, and the reasons expressed for making conclusions are also less precise. Found on the results of the students answers, information was obtained that the critical thinking skills of each student were classified as very less. Students are not accustomed to analyzing problems related to students critical thinking skills by identifying actual problems from questions, concepts, and descriptions and where students cannot make conclusions and assess questions or opinions with consideration. Students are required to do a lot of practice so that students critical thinking skills can improve (Synder, 2008).

\section{Student Response Questionnaire}

Table 2. Results of Student Response Questionnaires

\begin{tabular}{|c|c|c|}
\hline Questions & Yes $(\%)$ & No $(\%)$ \\
\hline Do you like physics subjects? & 80 & 20 \\
\hline $\begin{array}{l}\text { Do you think the matter of work and energy is important to } \\
\text { understand? }\end{array}$ & 96.8 & 3.2 \\
\hline Do you find the matter of work and energy difficult to understand? & 72.8 & 27.2 \\
\hline $\begin{array}{l}\text { Is the lecture method often used by teachers compared to } \\
\text { experimental-based learning in the laboratory in physics learning? }\end{array}$ & 92 & 8 \\
\hline $\begin{array}{l}\text { Have you ever conducted learning activities to increase critical } \\
\text { thinking skills? }\end{array}$ & 59.2 & 40.8 \\
\hline Have you ever been trained with critical thinking skills test questions? & 72.8 & 27.2 \\
\hline $\begin{array}{l}\text { Do you have difficulty when it comes to answering critical thinking } \\
\text { skills test questions? }\end{array}$ & 86.4 & 13.6 \\
\hline $\begin{array}{l}\text { Have you ever done RQA (reading, questioning, answering) } \\
\text { integrated problem based learning in physics learning? }\end{array}$ & 56.8 & 43.2 \\
\hline Do you feel bored if physics learning is done completely online? & 88.8 & 11.2 \\
\hline $\begin{array}{l}\text { Do you like the blended learning system (which combines online and } \\
\text { offline learning) in learning physics? }\end{array}$ & 60.8 & 39.2 \\
\hline
\end{tabular}

Based on the table above, the percentage of questionnaire scores that have been given via google form. In addition, $100 \%$ of students have chosen questions regarding interest in learning physics for work and energy materials, learning model provided by the teacher, critical thinking skills, PBLRQA model and the learning process is carried out using a blended learning system (combining online and offline learning) in physics learning. So it can be concluded that the less interest in learning physics learning. According to students, the material of work and energy is very important to understand because they are related in everyday life. However, students find it difficult to understand it. The learning model provided by the teacher tends to use the lecture method compared to the experimental method so that students rarely carry out learning activities to improve critical thinking skills and students rarely practice students critical thinking skills. Thus, students find it difficult when answering critical thinking skills test questions. In learning, they tend to use the lecture 
method and rarely do problem based learning. According to students in the teaching and learning process they feel bored if physics learning is done entirely online, so students enthusiasm is very high and interested if the learning process is carried out using a blended learning system. This statement is supported by the findings (Hasmunarti., et al, 2018) namely the use of technology in teaching and learning activities with the integrated blended learning model of PBLRQA can realize effective and interesting learning. One of them, such as laptops and smartphones.

\section{Teacher Interview}

Based on interviews with the physics teacher concerned, regarding the problems of learning models and students critical thinking skills. The following are the results of interviews conducted with teachers. Table 3 indicate the results of interviews that in the teaching and learning process activities that have been implemented by teachers tend not always to follow the design of the implementation of learning that has been made.

Table 3. Results of interview responses

\begin{tabular}{l} 
Interview Questions \\
\hline How do you usually teach \\
Physics concepts, especially the \\
matter of work and energy? \\
Have teacher ever carried out \\
physics lessons by training \\
students critical thinking skills?
\end{tabular}

Have teacher ever given questions to train students critical thinking skills?

In your opinion, what efforts can be made in learning to improve the profile of students critical thinking skills?

What is your response to the profile of students critical thinking skills conducted by the researcher?

In your opinion, if the RQA (Reading, Questioning, Answering) integrated problem based learning activities are carried out with a blended learning system with the aim of improving students critical thinking skills?

\section{Answers/Responses}

- First, invite students to understand the material given.

- Through discussion forums in the form of google classroom and meet using the lecture method.

- Other interactions via Whatsapp group.

- Very rarely.

- Because applying these skills requires a varied learning model with students higher order thinking.

- Students are also less enthusiastic about physics.

- Very rarely.

- Because critical thinking skills test of course includes indicators of high level skills.

- Less effective if given to students who lack interest in learning physics.

- The learning model given to students must of course make students interest increase.

- Presenting problems that make students curious to investigate.

- Very good.

- Critical thinking skills are also a challenge in the current century.

- Can be a reference in implementing the teaching and learning process.

- Very good.

- The learning provided used is suitable if it is used to make innovation students critical thinking skills.

- Because the profile of students critical thinking also tends to be low.

- Students will be excited and enthusiastic, because students have experienced the saturation of online learning.

Due to adjusting the conditions or situations of the teaching and learning process that takes place so that critical thinking skills tend to be categorized as low. This improvement in critical thinking requires a varied learning model, namely a problem based learning model 
with mixed learning (online and offline) because students feel bored with online learning. This is in line with research from (Marnita., et al, 2020) that problem based learning blended learning can improve critical thinking skills and student responses about learning models are very enthusiastic. From the results of students answers, it could be identified that in solving critical thinking skills questions there are still many students who are not precise with the question indicators that include analysis, evaluation, interpretation, and interference. Therefore, unsatisfactory results were obtained, namely getting a score with a very low category, but critical thinking skills are needed because they can be a reference in facing challenges and problems that arise in the 21 st century. Therefore, critical thinking skills are needed for students, so that they become the main focus in education as an important element of success. This agrees with the results of research (Sulaiman, 2016) which says that without critical thinking that is designed systematically, learning tends to be short. Related to this, critical thinking skills are not only focused on overcoming problems in learning but can also be developed with the aim of preparing students in the future to be able to solve problems of everyday life. When students are faced with a problem if students critical thinking skills are low, students cannot make decisions. This statement agrees with the results of research (Marnita, et al., 2020; Sarwi, et al., 2012) which says that one of the higher order thinking skills is students critical thinking skills when the process experienced by a person to make decisions that are relevant to what is being learned.

In this study using the material of work and energy may be seen the level of critical thinking skills. So it shows that students do not understand in this material so that students skills in solving problems are not optimal. It can be identified several factors that cause students difficulties in completing tests of students critical thinking skills, namely the learning method that tends to use the lecture method and is rarely trained in critical thinking skills tests which causes the learning process to be not optimal and learning objectives are not achieved.

Research on business and energy materials was conducted by Sucirahayu et al (2015) who stated that agreeing with the application of problem based learning can improve critical thinking skills in works and energy materials. The results of the study also stated that students were very enthusiastic if blended learning was carried out. The blended learning strategy is very important to use with the aim of being more effective as a means of teaching and learning processes in schools (Hasmunarti, et al., 2018). This is in line with research conducted (Korkmaz \& Karakusm, 2009; Garrison \& Vaughan, 2008) that the effect of blended learning on students can improve critical thinking skills.

From these problems, the PBLRQA learning model strategy can increase students critical thinking skills. Because this learning model strategy presents an authentic problem and student centered problems are so that students can develop thinking power in the context of solving problems that arise. Several research results show the potential for PBLRQA to be able to develop learning motivation (Bahri \& Corebima 2015), make students independent in the learning process (Hasmunarti, et al., 2018), can increase students critical thinking skills (Bahri, A. 2017).

Based on the problems expressed, it is necessary to innovate learning models in the learning process that is more effective so that learning objectives can be achieved, namely to improve students critical thinking skills. One of the learning models needed is student centered learning by solving authentic problems, namely the problem based learning strategy with reading, questioning, and answering (PBLRQA) based on blended learning. The results of the research analysis presented can be useful for assessing the effectiveness of the problem based and reading, questioning, \& answering (PBLRQA) learning model based on blended learning to increase students critical thinking skills. The selected studies include research conducted in 2013, 2018, 2019, 2020, and 2021. A summary of the relevant research analysis can be seen in Table 4 . 
Table 4. Review of 2013-2021 studies

\begin{tabular}{ll}
\hline $\begin{array}{l}\text { Author } \\
\text { (year) }\end{array}$ & Research Title \\
\hline $\begin{array}{l}\text { Alotabi, K. } \\
\text { N. R. }\end{array}$ & The Effect of Blended \\
(2013). & Learning on Developing \\
& Critical Thinking Skills.
\end{tabular}

Sulaiman, F. The effectiveness of PBL (2013). Online on Physics Students Creativity and Critical Thinking: A Case Study at Universiti Malasyia Sabah

Hasmunarti., Needs Analysis

Bahri A., Development of Integrated Idris. I. A. Blended Learning Strategy (2018). problem based learningRQA in Biology Learning.

Bahri, A., \& Corebima,

A., D.

(2019)

Bakri, F., Permana, $\mathrm{H}$ The Implementation of Vani, N. D., Muliyati, D. (2020)

Marnita., M. The Effect of Blended Taufiq., Learning Problem Based Iskandar., Instruction Model on Rahmi. (2020). Students Critical Thinking Ability in Thermodynamic Course.

Rahmawati, Developing Physics

U. R., Learning Tools of Blended Jumadi., Learning Using Schoology

Ramadan, E. with Problem-Based

M. (2020) Learning Model.

Bahri, A., Idris, I. S. Muis, H., Blended Learning Muis, H., Integrated with Innovative Learning Strategy to Improve Self Regulated M., Fikri, M. Learning. J. (2021)

\section{Finding}

- This research is experimental design.

- The study used the influence of the independent variable on the dependent variable.

- Research subjects were selected randomly.

- The results indicated that there was a statistically significant difference between the experimental and control groups.

- This study has an experimental design with experimental and control groups.

- The data analysis technique used the Mann-Whitney U test.

- The results obtained substancial data regarding the online PBL learning model with the lecture method, statistically in the creativity and critical thinking of physics students.

- The research design is descriptive research.

- Data were collected qualitatively and analyzed descriptively with the triangulation of method.

- The use of technology in learning with the PBL-RQA based on blended learning model can create effective and interesting learning on the use of electronic media.

- Quasi experimental design research.

- The research design used was pretest posttest nonequivalent control group design.

- The result of the research is that PBL teaching learning strategies will be more effective if they are combined with RQA.

- This research is descriptive qualitative.

- Data were collected using observation sheets from the initial, core, and final learning stages.

- The result of this research is the application of the PBL concept of elasticity with an increase of $18 \%$ at the stage of organizing students in the learning process.

- The research is a quasi-experimental design.

- Data analysis using T-test.

- Implementation of blended learning based problem based instruction can indicate students critical thinking skills.

- Student responses to problem based instruction based on blended learning were enthusiastic.

- $\quad$ Research using 4D models (definition, design, development, and deployment).

- Collecting data using interviews, observations, and questionnaires.

- Data validation using quantitative and qualitative data.

- The result of the average student response show in the good category.

- Research is a design and development.

- The sampling technique is random.

- The results of using technology from lesson plans, evaluation, and e-learning based on valid moodle integrating the PBLRQA strategy are feasible to use.

Based on this description, there is a relevant type of research that has been done before. With the results of the research that the PBL learning model is proven to be able to improve the profile of students critical thinking skills compared to the previous learning model. With the help of reading, questioning, and answering (RQA) strategies, it can also improve students critical thinking skills, especially physics material. This has been tested from the learning model and from various tests that have been carried out. Furthermore, the blended 
learning model system can also improve critical thinking skills. So that by using a learning model in improving critical thinking skills, namely by using the problem based learning and reading, questioning, \& answering (PBLRQA) learning model based on blended learning.

\section{CONCLUSION}

From the results and discussion listed, it can be concluded that the critical thinking skills of students at Kabuh state high school are in the very low category of the written test of students critical thinking skills with indicators of interpretation, analysis, evaluation and inference. On the indicators of students critical thinking skills, the results show that from higher to lower, starting from indicators of analysis, evaluation, inference, and interpretation. Based on student response questionnaires and teacher interviews, it shows that students critical thinking skills need to be trained by teachers in each school and it is necessary to make changes to the learning model carried out. Therefore, based on the conclusions of the study, the research recommends a change in innovative and creative learning models to make innovative students critical thinking skills based on critical thinking skills indicators, namely by using the problem based learning and reading, questioning, \& answering (PBLRQA) learning model based on blended learning.

\section{RECOMMENDATION}

It is recommended for teachers to implement PBLRQA based on blended learning models to make innovative students critical thinking skills in line with $21^{\text {st }}$ century learning needs. Model PBLRQA based on blended learning can make various alternative learning models to help students think critically and increase students interest so that they are not bored when carry out teaching and learning activities.

\section{ACKNOWLEDGMENT}

This research received no specific grant from any funding agency in the public, commercial, or not-for-profit sectors.

\section{REFERENCES}

Alexander, L. (2000). Education \& Training On The Internet. An essensial resources for students, teachers and education providers. UK: Internet Handbook.

Asrizal, A., Amran, A., Ananda, A., Festiyed. (2019). Effects of Instructional Material Of Natural Science with Literacy Skills of Our Respiratory And Excretory Health Theme On Academic Achievement Of Student. Journal of Physic: Conference Series, 1317(012174), 1-7.

Bahri, A., Idris, I.S., Muis, H., Arifuddin, M., Fikri, M. J. N. (2021). Blended Learning Integrated with Innovative Learning Strategy to Improve Self-Regulated Learning. International Journal of Instruction, 14(1), 779-794.

Bahri, A., Corebima. A. D. (2019). Improving PBL in Empowering Meta cognitive Skills of Student. Indian Journal of Science and Technology, 12(17), 1-9.

Bakri, F., Permana, H., Vani, N. D., Mulyati, D. (2021). The implementation of problem based learning in elasticities concept. AIP Conference Proceedings, 2320,020001, 1-6.

Deore, K. V. T. (2012). The Educational Advantages of Using Internet. International Educational E-Journal, 1(2), 111-112.

Ennis, R. H. (2011). The Nature of Critical Thingking Assesment. Retreived March 26, 2021 from

http://www3.qcc.cuny.edu/WikiFiles/file/Ennis\%20Critical\%Thinking\%20Assesment.p $\mathrm{df}$

Facione, A.P. (2011). Holistic Critical Thinking Scoring Rubric. California Academia Press: San Fransisco.

Facione. (2013). Critical Thinking: What It Is and Why It Counts. Millbrae, CA: Measured Reasons and The California Academic Press. 
Forsyth, I. (2001). Teaching and Learning Materials and The Internet. $3^{\text {rd }}$ Edition. USA.

Garisson, R., \& Vaughan, H. (2008). Blended Learning in higher education; Framework, principles and guidelines. San Francisco: Jossey-Bass.

Hasmunarti., Bahri, A., Idris, I. S. (2018). Analisis Kebutuhan Pengembangan Blended Learning Terintegrasi Strategi PBLRQA (Problem Based Learning and Reading, Questionary \& Answering) pada Pembelajaran Biologi. Jurnal Biology Teaching and Learning, 1(2), 101-108.

Korkmaz, O., \& Karakusm, U. (2009). The impact of bended learning models o student attitudes towards Gepgraphy course and their Critical Thinking dispositions and levels. The Turkish Online Journal of Educational Technology, 8(4), 51-63.

Listiana, L., Raharjo., Hamdani. A. S. (2020). Enhancing Self-Regulation Skills through Group Investigation Integrated with Think Talk Write. International Journal of Instruction, 13(1), 915-930.

Marnita., M. Taufiq., Iskandar., Rahmi. (2020). The Effect of Blended Learning ProblemBased Instruction Model on Student's Critical Thinking Ability in Thermodynamic Course. Jurnal Pendidikan IPA Indonesia, 9(3), 430-438.

Mundilarto., \& Ismoyo, H. (2017). Effect Of Problem-Based Learning on Improvement Physics Achievement And Critical Thinking of Senior High School Student. Journal of Baltic Science Education, 16(5), 761-780.

Patnership for 21 ${ }^{\text {st }}$ Century Skills (P21). (2009). Retreived March 26, 2021 from http://www.p21.org/our-work/p21-framework

Prameswari, S.W., Suharno., Sarwanto. (2018). Inculcate Critical Thinking Skills in Primary Schools. SHEs: Coference Series, 1(1), 742-750.

Rahmawati, D.U., Jumadi., Ramadan, E. M. (2020). Developing Physics Learning Tools of Blended Learning Using Schoology with Problem-Based Learning Model. JPPPF (Jurnal Penelitian dan Pengembangan Pendidikan Fisika), 6(2), 139-152.

Ricketts, J.C. (2004). Critical thinking skills of FFA leaders. Journal of Southern Agricultural Eduaction Research, 54(1), 7-20.

Rosenthal, D. dan Weit, R. (2012). Large-Course Redesign via Blended Learning: A PostImplementation Assesment Across Institutions. International Journal on E-Learning, 11(2), 189-207.

Sarwi, A., Rusilowati, A., Khanafiyah S. (2012). Implementasi Model Eksperimen Gelombang Open-Inquiry Untuk Mengembangkan Kemampuan Berpikir Kritis Mahasiswa Fisika. Jurnal Pendidikan Fisika Indonesia, 8(1), 41-50.

Sharma, P. (2010). Blended Learning. ELT Journal, 64(4), 456-458.

Sucirahayu, S., Halim, A., Idris, N. (2015). Penerapan Model Problem Based Learning (PBL) pada Konsep Usaha dan Energi Untuk Meningkatkan Keterampilan Berpikir Kritis dan Berpikir kreatif Siswa SMA. Indonesian Jurnal of Science, 3(1), 207-217.

Sugiyono. (2010). Metode Penelitian Pendidikan Pendekatan Kuantitatif, kualitatif, dan $R \& D$. Bandung: Alfabeta.

Sulaiman, F. (2013). The Effectiveness of PBL Online on Physics Student's Creativity and Critical Thinking: A Case Study at University Malasyia Sabah. International Journal of Education and Research, 1(3), 1-18.

Sungur, S., \& Tekayya, C. (2006). Effects of problem-based learning and traditional instruction on self-regulated learning. The Journal of Educational Research, 99(5), 307-320.

Susilawati., Ristanto, S., Khoiri, N. (2015). Pembelajaran Real Laboratory dan Tugas Mandiri Fisika pada Siswa SMK sesuai dengan Keterampilan Abad 21. Jurnal Pendidikan Fisika Indonesia, 11(1), 73-83.

Synder, L. G., dan Synder, M. J. (2008). Teaching Critical Thinking and Problem Solving Skills. The Delta Pi Epsilon Journal, 1(2), 90-99. 
Witelson, S. F., Glezzer, I.I., Kigar, D.L. (1995). Women Have Greater Density of Neurons in Posterior Temporal Cortex. The Journal of Neuroscience, 15(5), 3418-3428.

Yulianti, D. (2016). Problem-Based Learning Model Used to Scientific Approach Based Worksheet for Physics to Develop Senior High School Students Characters. Journal of Physic: Conference Series, 824(012009), 1-6.

Yuliati, L., Fauziah, R., Hidayat, A. (2018). Student's Critical Thinking Skills in Authentic Problem Based Learning. Journal of Physic: Conference Series, 1013(012025), 1-7. 